\title{
ANALISIS KESESUAIAN APB DES DENGAN PERENCANAAN PEMBANGUNAN DESA BERDASARKAN PP 43 TAHUN 2014 DI DESA KALIGADING KECAMATAN BOJA KABUPATEN KENDAL PROPINSI JAWA TENGAH
}

\author{
Penta Widyartati, Ariyani Indriastuti \\ Prodi Akuntansi, Prodi Managemen STIE SEMARANG \\ penta@stiesemarang.ac.id, ariyani@stiesemarang.ac.id
}

\begin{abstract}
The Village Revenue and Expenditure Budget (APBDes) is the annual financial plan of the village government that is discussed and agreed upon jointly by the village government and Village Consultation, and is determined by village regulations. The mechanism for using village funds starts from the planning, implementation, accountability and utilization of village funds. In order for the use of village funds to be targeted and in accordance with the priorities of community needs, the planning process as a basis for implementing village funds is expected to be carried out in accordance with Government Regulation No. 43 of 2014 article 114 and article 117. From the results of the study obtained evidence that the Kaligading Village government has carried out the mandate in accordance with Government Regulation No. 43 of 2014 article 114 concerning deliberation for the screening of community aspirations which then results from the deliberations set forth in the RPJMDes.
\end{abstract}

Keyword: Village Fund, Adjustable Planning, Village Development, APBDes Management

\begin{abstract}
ABSTRAK
Anggaran Pendapatan dan Belanja Desa (APBDes) adalahrencana keuangan tahunan pemerintahan desa yang dibahas dan disetujui bersama oleh pemerintah desa dan Badan Permusyawaratan Desa, dan ditetapkan dengan peraturan desa. Mekanisme penggunaan dana desa dimulai dari perencanaan, pelaksanaan, pertanggungjawaban dan pemanfaatan dana desa. Agar penggunaan dana desa sesuai sasaran dan sesuai dengan prioritas kebutuhan masyarakat, proses perencanaan sebagai dasar pelaksanaan dana desa diharapkan dapat dilakukan sesuai dengan yang tercantum dalam PP No. 43 tahun 2014 pasal 114 dan pasal 117. Dari hasil penelitian diperoleh bukti bahwa pemerintah Desa Kaligading sudah melaksanakan amanat sesuai dengan PP No. 43 tahun 2014 pasal 114 tentang musyawarah untuk penjaringan aspirasi masyarakat yang kemudian hasil musyawarah tersebut dituangkan dalam RPJM Des.
\end{abstract}

Kata kunci: dana desa, perencanaan, kesesuaian, pembangunan desa, penyusunan APBDes

\section{PENDAHULUAN}

Dana Desa adalah dana yang bersumber baik dari APBN, APBD, Pendapatan Asli Daerah dan lain-lain yang diperuntukkan bagi Desa dan Desa Adat yang ditransfer melalui Anggaran Pendapatan dan Belanja Daerah kabupaten/kota dan digunakan untuk membiayai penyelenggaran pemerintahan, pembangunan, serta pemberdayaan masyarakat, 
dan kemasyarakatan. Dana desa yang dikucurkan dari APBN tersebut masuk ke rekening desa sebagai keuangan desa.

Dana Desa diperuntukkan bagi Desa dan Desa Adat dan ditransfer melalui Anggaran Pendapatan dan Belanja Daerah kabupaten/kota dan digunakan untuk membiayai penyelenggaran pemerintahan, pembangunan, serta pemberdayaan masyarakat, dan kemasyarakatan.

Dana desa mulai dikucurkan di desa-desa pada tahun 2015 sebagai realisasi dari berlakunya Undang Undang Desa (UU No 6 tahun 2014). Pemerintah telah mengucurkan dana desa sebanyak Rp. 20,70 trilyun pada tahun 2015 untuk dikucurkan kepada 74.093 desa. Tahun anggaran 2016 jumlah kucuran dana desa justru semakin meningkat yakni menjadi Rp.46,98 trilyun (Kompas, 10 April 2016).Propinsi Jawa Tengah pada tahun 2016 menerima $\begin{array}{lllll}\text { kucuran } & \text { dana } & \text { sebanyak } & \text { Rp. }\end{array}$ www.djpk.kemenkeu.go.id/web/attachments/article/608/DANA DESAdiperuntukan bagi 7.809 desa dan tahun 2017 dana desa meningkat menjadi 60 triliun yang akan dibagikan pada 74.954 desa di seluruh wilayah Indonesia.

Dari dana tersebut, alokasi untuk Kabupaten Kendal untuk tahun anggaran 2017 adalah lebih dari Rp. 212 milyar dengan alokasi yang berbeda-beda untuk setiap desanya tergantung dari kriterianya. Kriteria tersebut berdasarkan luas desa, jumlah penduduk, jumlah penduduk miskin, dan jangkauan desa atau letak geografis dari ibukota Kecamatan.

Kucuran dana tersebut dimaksud untuk mendukung program-program pembangunan dan pemberdayaan masyarakat desa sebagaimana diamanatkan oleh Undang Undang Desa. Dengan kata lain dana desa dimaksud untuk menopang upaya meningkatkan kesejahteraan masyarakat desa melalui program-program yang diperlukan sesuai dengan masalah dan aspirasi masyarakat desa.

Untuk dapat menampung aspirasi masyarat desa menurut PP 43 tahun maka Perencanaan pembangunan Desa disusun berdasarkan hasil kesepakatan dalam musyawarah Desa. Oleh karena itu dalam penelitian ini memfokuskan pada kesesuaian antara perencanaan pembangunan desa dengan APBDes.

\section{MASALAH PENELITIAN}

Dari latar belakang penelitian di atas maka dapat dirumuskan masalah dalam penelitian ini adalah:

1. Dalam perencanaan/penganggaran, sudahkan dibentuk pihak-pihak: 
a. Badan Permusyawaratan Desa / BPD sebagai pihak legislasi desa?

b. Lembaga perencanaan masyarakat desa sebagai badan perencanaan pembangunan desa?

c. Perwakilan dari kelompok-kelompok masyarakat yang akan terlibat dalam pengawasan perencanaan dan pelaksanaan pembangunan di tingkat desa

2. Dalam perencanaan/penganggaran, bagaimanakah keterlibatan forum-forum:

a. Musyawarah desa (Musdes) di tingkat dusun dan desa

b. Masyarakat pembangunan desa (Musrenbang) di tingkat dusun maupun desa)

c. Musyawarah / kelompok-kelompok masyarakat sebagai sarana sinkronisasi perencanaan program pembangunan dan penganggaran

3. Apakah musyawarah desa diawali dengan musyawarah dusun?

4. Apakah kesepakatan dalam musdes menjadi landasan bagi penyusunan RPJMDes?

5. Apakah RKPDes didasari oleh RPJMDes?

6. Apakah penyusunan APBDes didasari dengan RKPDes?

\section{KAJIAN TEORITIS}

Pembangunan Desa

Pembangunan desa merupakan upaya pembangunan yang berorientasi pada upaya peningkatan standar hidup yang lebih baik. Hal tersebut disebabkan karena kenyataan menunjukkan bahwa standar hidup di pedesaan terbukti masih lebih rendah dibanding dengan standar hidup di perkotaan. Pemerintahan Susilo Bambang Yudoyono (2009 - 2014) telah memetakan dan menetapkan berbagai hal berkenaan dengan pembangunan perdesaan.

Sebagai upaya pembangunan desa maka dikucurkan dana desa bagi tiap-tiap desa di seluruh wilayah Indonesia. Dana Desa adalah dana yang bersumber baik dari APBN, APBD, Pendapatan Asli Daerah dan lain-lain yang diperuntukkan bagi Desa dan Desa Adat yang ditransfer melalui Anggaran Pendapatan dan Belanja Daerah kabupaten/kota dan digunakan untuk membiayai penyelenggaran pemerintahan, pembangunan, serta pemberdayaan masyarakat, dan kemasyarakatan. Dana desa yang dikucurkan dari APBN tersebut masuk ke rekening desa sebagai keuangan desa.

Keuangan desa adalah semua hak dan kewajiban desa yang dapat dinilai dengan uang, serta barang/uang yang dijadikan milik desa terkait dengan pelaksanaan hak dan kewajiban yang dikelola dengan pengelolaan keuangan desa. 
Pengelolaan keuangan desa adalah keseluruhan kegiatan yang meliputi perencanaan, penganggaran, penata-usahaan, pelaporan, pertanggungjawaban dan pengawasan keuangan desa. Penganggaran keuangan desa adalah metode pengalokasian sumber penerimaan dan pengeluaran desa dalam jangka waktu tertentu (biasanya 1 tahun) yang disebut APBDes.

APBDes atau Anggaran Pendapatan dan Belanja Desa adalah rencana keuangan tahunan pemerintah desa yang dibahas dan disetujui bersama oleh pemerintah desa dan Badan Permusyawaratan Desa, dan ditetapkan dengan peraturan desa.

Pihak-pihak yang terlibat dalam perencanaan dan penganggaran desa adalah:

- Pemerintah desa sebagai eksekutif desa

- $\quad$ Badan Permusyawaratan Desa/BPD sebagai pihak legislatif desa

- Lembaga perencanaan masyarakat desa sebagai badan perencanaan pembangunan desa

- Perwakilan dan kelompok masyarakat sebagai unsur yang akan terlibat dalam pengawasan perencanaan dan pelaksanaan pembangunan di tingkat desa

\section{Forum Pendukung}

Forum-forum yang mendukung adalah:

- $\quad$ Forum musyawarah desa (Musdes) di tingkat dusun dan desa

- Forum musyawarah pembangunan desa (Musrenbangdes) di tingkat dusun maupun desa

- $\quad$ Forum-forum musyawarah kelompok-kelompok masyarakat sebagai sarana sinkronisasi perencanaan program pembangunan dan penganggaran

\section{Mekanisme Penyusunan APBDes}

Mekanisme penyusunan APBDes adalah sebagai berikut:

- Musyawarah Dusun (Musdes) dilaksanakan pada bulan Oktober-November tahun sebelumnya

- Hasil Musyawarah Dusun disampaikan pada Badan Permusyawaratan Desa

- Hasil Musdus dimusyawarahkan dalam Musyawarah Desa (Musdes)

Musdes membahas tentang arah dan rencana serta prioritas pembangunan desa selama 6 tahun dan sumber pembiayaan kegiatan dan pelaksana pembangunan desa

- Hasil Musdes dituangkan dalam berita acara menjadi landasan penyusunan Rancangan Rencana Pembangunan Jangka Menengah Desa (RPJM Des).

- Rancangan RPJM Des dan berita acara diserahkan kepada Kepala Desa 
- Kepala desa memeriksa Rancangan RPJM Desa dan memberikan masukan yang diperlukan

- Pemerintah Desa menyelenggarakan Musyawarah Perencanaan Pembangunan Desa (Musrenbangdes) untuk membahas dan menyepakati RPJM Des yang telah dibuat

- Tim RPJM Des melakukan perbaikan dokumen Rancangan RPJMDes berdasarkan masukan dalam proses Musrenbangdes

- Rancangan RPJM Des yang sudah diperbaiki diserahkan kepada Kepala Desa dan digunakan sebagai lampiran dalam Rancangan Peraturan Desa

- Kepala desa membuat rancangan Perdes tentang RPJMDes. Rancangan Peraturan Desa tentang RPJMDes dibahas dan disepakati bersama oleh Kepala Desa dan BPD untuk ditetapkan secara bersama sebagai Perdes RJPMDes.

- Pemerintah desa menyusun RKPDes (Rencana Kerja Pembangunan Desa). RKPDes ditetapkan dengan Perdes paling lambat pada bulan September tahun berjalan melalui proses Musrenbangdes. Kemudian dibuat penetapan APBDes berdasarkan RKPdes tersebut.

\section{METODOLOGI}

Populasi dan Sampel Penelitian

Penelitian ini merupakan pengembangan dari penelitian sebelumnya yang berjudul “Analisis Pelaksanaan Anggaran Belanja Desa Tahun Anggaran 2016 di Wilayah Kabupaten Kendal” yang dilaksanakan tahun 2017 dengan jumlah sampel 13 desa. Dari penelitian yang telah dilakukan tersebut diperoleh hasil bahwa di antara desa-desa tersebut, Desa Kaligading merupakan desa yang dalam pelaksanaan penggunaan Anggaran Desa nya telah mengarah pada BUMDes.

Dengan demikian dapat disimpulkan bahwa yang menjadi populasi dalam penelitian ini adalah 13 desa yang diteliti pada penelitian sebelumnya.

Sedangkan pemilihan sampel dilakukan dengan teknik purposive sampling dengan kriteria desa yang diambil sebagai sampel adalah desa yang dalam pelaksanaan penggunaan anggaran desa tahun 2016 telah mengarah pada BUMDes. 
Variabel Penelitian

Variabel penelitian ini meliputi

1. Perencanaan/penganggaran, tentang keterlibatan pihak-pihak:

a. Badan Permusyawaratan Desa / BPD sebagai pihak legislasi desa

b. Lembaga perencanaan masyarakat desa sebagai badan perencanaan pembangunan desa

c. Perwakilan dari kelompok-kelompok masyarakat yang akan terlibat dalam pengawasan perencanaan dan pelaksanaan pembangunan di tingkat desa

2. Perencanaan/penganggaran, tentang keterlibatan forum-forum:

a. Musyawarah desa (Musdes) di tingkat dusun dan desa

b. Masyarakat pembangunan desa (Musrenbang) di tingkat dusun maupun desa)

c. Musyawarah / kelompok-kelompok masyarakat sebagai sarana sinkronisasi perencanaan program pembangunan dan penganggaran

3. Musyawarah desa yang diawali dengan musyawarah dusun

4. Landasan bagi penyusunan RPJMDes

5. Dasar RKPDes

6. Dasar penyusunan APBDes

Metode Pengumpulan Data

Pengumpulan data yang diperlukan dalam penelitian ini dilakukan melalui beberapa pendekatan, yakni : 1) Dokumentasi dan 2) Wawancara, Metode dokumentasi digunakan untuk menghimpun data dan dokumen-dokumen yang menjadi dasar penyusunan APB Desa, sedang wawancara digunakan untuk menghimpun data atau informasi tentang berfungsi tidaknya lembaga-lembaga dan forum-forum yang berkaitan dengan pembangunan desa.

Metode Analisis

Analisis data yang digunakan dalam penelitian ini adalah analisis deskriptif,yaitu memberikan gambaran tentangPerencanaan Pembangunan Desa Terhadap Penyusunan APB Desa. 
Tahap-tahap penelitian

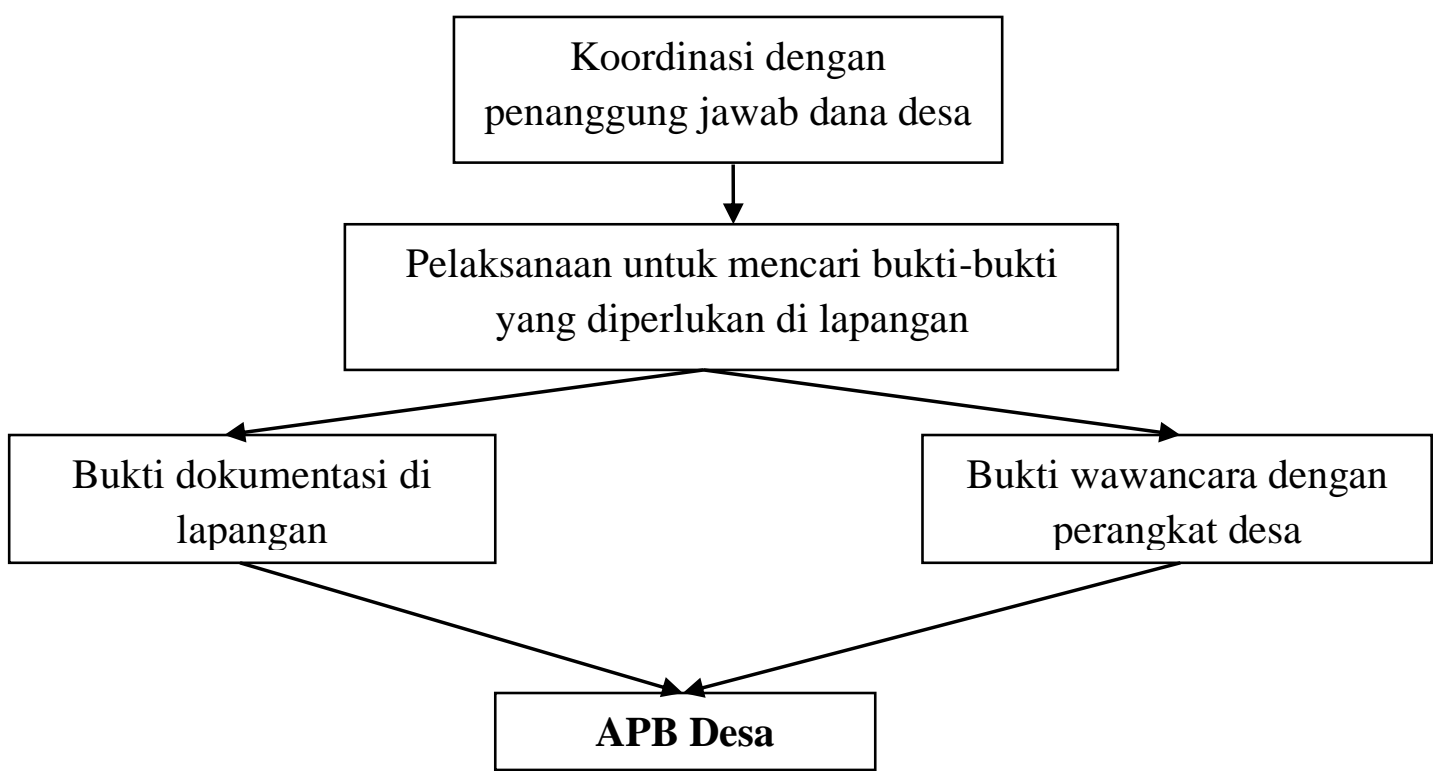

Lokasi penelitian ini adalah di Desa Kaligading Kecamatan Boja Kabupaten Kendal Propinsi Jawa Tengah. Lokasi ini dipilih karena dari penelitan terdahulu diperoleh hasil bahwa dari beberapa sampel desa yang dipilih, Desa Kaligading termasuk salah satu desa yang dalam penggunaan Dana Desa sudah mulai mengarah pada BUMDes.

Dari data-data yang dihimpun kemudian dianalisis perencanaan penggunaan APBDes tersebut telah sesuai dengan perencanaan yang sudah ditetapkan berdasarkan ketentuan dalam PP 43 tahun 2014.

\section{PEMBAHASAN}

Dalam menyusun APBDes, dilakukan dengan menggunakan tiga alat penjaringan aspirasi. Alat aspirasi tersebut adalah badan kelembagaan masyarakat, kalender musim dan sketsa desa.

Badan kelembagaan masyarakat desa yang dimaksud adalah kumpulan wadah untuk mengemban tugas dan fungsi Pemerintahan Desa. Tujuan penyelenggaraan pemerintah Desa adalah untuk meningkatkan kesejahteraan masayarakat, sehingga tugas pemerintah desa adalah memberikan pelayanan (service) dan pemberdayaan (empowerment), serta pembangunan (development) yang seluruhnya ditujukan bagi kepentingan masyarakat. Badan kelembagaan desa tersebut antara lain misalnya kumpulan RT, kumpulan RW, posyandu, karang taruna, PKK, tahlil, selapanan dan lain-lain.

Kalender musim adalah alat kajian untuk mengetahui kejadian dan/atau kegiatan dalam kehidupan masyarakat berkaitan dengan perubahan waktu dan terjadi secara berulang- 
ulang. Kalender musim yang dimaksud berfungsi untuk mengidentifikasi kebutuhan masyarakat berdasarkan musim. Sebagai contoh, pada musim kemarau masalah yang sering timbul adalah masalah kekurangan air bersih dan masalah kekeringan lahan. Sedangkan pada musim penghujan, masalah yang sering timbul adalah potensi adanya banjir dan banyaknya penyakit menular. Dari kalender musim tersebut maka dapat diidentifikasikan masalah beserta pencegahan dan penanggulangan masalah yang timbul.

Sketsa desa adalah alat untuk menggali masalah yang berhubungan dengan keadaan sumber daya pembangunan dan potensi yang tersedia untuk mengatasi masalah. Hasilnya dapat berupa masalah sosial, ekonomi, pendidikan, kesehatan, keamanan baik fisik maupun non fisik. Implentasi riil dari sketsa desa adalah dengan penggalian masalah dan potensi desa tersebut maka dapat diidentifikasi sumber daya dan kebutuhan pada tiap-tiap daerah pada desa yang bersangkutan. Sebagai contoh ada dusun di suatu desa yang membutuhkan perbaikan talud karena talud telah rusak. Hal ini dapat diketahui dengan penjaringan aspirasi dengan sketsa desa.

Salah satu alat penjaringan aspirasi dimulai dari kelembagaan yang ada di masyarakat misalnya seperti kumpulan RT, kumpulan RW, posyandu, karang taruna, PKK, tahlil, selapanan dan lain-lain yang ada di desa. Aspirasi dari beberapa kelembagaan kemasyarakatan tersebut kemudian dikumpulkan dan dimusyawarahkan dengan tokoh-tokoh masyarakat dalam musyawarah desa (Musdes). Dari Musyawarah Dusun dibahas tentang prioritas pembangunan desa yang akan dilaksanakan yang kemudian dituangkan dalam RPJM Des. RPJM Des tersebut hanya membahas tentang prioritas pembangunan yang akan dilaksanakan. Sedangkan untuk detail biaya yang diperlukan dituangkan dalam RKP Des. RKP Des tersebut digunakan sebagai dasar untuk penetapan APBDes.

Dari bukti-bukti penelitian berupa bukti dokumentasi dan bukti wawancara dengan perangkat desa, maka didapatkan hasil sebagai berikut:

- Musyawarah Dusun (Musdes) dilaksanakan pada bulan Oktober-November tahun sebelumnya

Musyawarah dusun sudah dilaksanakan pada bulan November 2017. Sehingga perencanaan dalam hal musdes sudah sesuai dengan apa yang ditetapkan dalam Undangundang.

- Hasil Musyawarah Dusun disampaikan pada Badan Permusyawaratan Desa Hasil musyawarah dusun yang dirangkum dari aspirasi masyarakat telah disampaikan pada Badan Permusyawaratan Desa. 
- Hasil Musdus dimusyawarahkan dalam Musyawarah Desa (Musdes)

Musdes membahas tentang arah dan rencana serta prioritas pembangunan desa selama 6 tahun dan sumber pembiayaan kegiatan dan pelaksana pembangunan desa

- Dari Musdus yang menampung aspirasi masyarakat kemudian aspirasi dimusyawarahkan kembali di musyawarah desa. Dalam musyawarah desa tersebut kebutuhan masyarakat dirumuskan menurut prioritas. Kebutuhan yang menjadi prioritas utama akan diusahakan dijalankan terlebih dahulu. Sedangkan kebutuhan-kebutuhan yang tidak tercover dana desa tahun ini akan menjadi prioritas tahun selanjutnya setelah diadakan musyawarah kembali pada tahun berikutnya.

- Hasil Musdes dituangkan dalam berita acara menjadi landasan penyusunan Rancangan Rencana Pembangunan Jangka Menengah Desa (RPJM Des).

Dari rumusan prioritas hasil musyawarah desa, kemudian hasil musdes tersebut kemudian dihitung kebutuhan dana yang diperlukan untuk melaksanakan pembangunan yang sudah menjadi keputusan pembangunan desa tersebut. Setelah kebutuhan anggaran ditentukan, maka hasil musdes beserta kebutuhan dananya tersebut dituangkan dalam Rancangan RPJM Des. Sehingga isi dari Rancangan RPJM Des tersebut adalah prioritas pembangunan desa beserta anggaran dana yang dibutuhkan oleh masing-masing proyek pembangunan.

- Rancangan RPJM Des dan berita acara diserahkan kepada Kepala Desa

Setelah Rancangan RPJM Des tersebut selesai dirumuskan, Rancangan RPJM Des tersebut diserahkan kepada Kepala Desa untuk dievaluasi kembali oleh Kepala Desa.

- Kepala desa memeriksa Rancangan RPJM Desa dan memberikan masukan yang diperlukan

Setelah Ramcangan RPJM Des tersebut diterima oleh Kepala Desa, Kepala Desa mengevaluasi kembali rancangan RPJM Des tersebut, kemudian kepala desa memberikan masukan apabila ada hal-hal yang memerlukan masukan dari kepala desa.

- Pemerintah Desa menyelenggarakan Musyawarah Perencanaan Pembangunan Desa (Musrenbangdes) untuk membahas dan menyepakati RPJM Des yang telah dibuat Setelah kepala desa mengevaluasi dan memberi masukan yang diperlukan atas RPJM Des, kepala desa kemudiam menyelenggarakan Musyawarah Perencanaan Pembangunan Desa (Musrenbangdes) yang dihadiri oleh tokoh masyarakat desa untuk membahas dan menyepakati RPJM Des yang telah dibuat. 
- Tim RPJM Des melakukan perbaikan dokumen Rancangan RPJMDes berdasarkan masukan dalam proses Musrenbangdes

Pada Musrenbangdes yang dihadiri oleh tokoh masyarakat tersebut Tim RPJM Des mengevaluasi kembali RPJM Des yang disampaikan oleh kepala desa. Kemudian Tim RPJM Des melakukan perbaikan yang diperlukan berdasarkan masukan dari anggota Tim RPJM Des.

- Rancangan RPJM Des yang sudah diperbaiki diserahkan kepada Kepala Desa dan digunakan sebagai lampiran dalam Rancangan Peraturan Desa.

Setelah Tim RPJM Des melakukan revisi dan masukan terhadap RPJM Des, kemudian RPJM Des tersebut diserahkan kembali kepada kepala desa dan akan digunakan sebagai lampiran dalam Rancangan Perdes untuk pelaksanaan RPJM Des.

- Kepala desa membuat rancangan Perdes tentang RPJMDes. Rancangan Peraturan Desa tentang RPJMDes dibahas dan disepakati bersama oleh Kepala Desa dan BPD untuk ditetapkan secara bersama sebagai Perdes RJPMDes.

Setelah Tim RPJM Des mengevaluasi dan merevisi RPJM Des kemudian kepala desa bersama dengan BPD menetapkan rancangan perdes tersebut menjadi perdes RPJMDes.

- Pemerintah desa menyusun RKPDes (Rencana Kerja Pembangunan Desa). RKPDes ditetapkan dengan Perdes paling lambat pada bulan September tahun berjalan melalui proses Musrenbangdes. Kemudian dibuat penetapan APBDes berdasarkan RKPdes tersebut.

Setelah Perdes ditetapkan, langkah kepala desa kemudian menetapkan RKPDes berdasarkan dari perdes tersebut. Setelah RKP Des ditetapkan, RKP Des tersebut akan menjadi dasar ditetapkkannya APBDes. Dari APBDes inilah yang akan menjadi acuan utama dalam pelaksanaan pembangunan desa. APBDes ini mempunyai fungsi otorisasi, perencanaan, pengawasan, alokasi, distribusi dan stabilisasi dalam pembangunan desa.

\section{KESIMPULAN}

Dari hasil penelitian dan pengumpulan bukti pada kedua desa maka dapat disimpulkan bahwa dalam menyusun APBDes kedua desa tersebut telah melakukan semua prosedur seperti yang dimaksud dalam PP No. 43 tahun 2014 yang mengamanatkan bahwa dalam APBDes harus disusun berdasarkan amanat dari masyarakat desa. Hal ini ditunjukkan dengan keterlibatan lembaga-lembaga kemasyarakatan yang ada di desa yang digunakan sebagai salah satu alat untuk menjaring aspirasi rakyat. Kelembagaan masyarakat yang dimaksud 
misalnya seperti kumpulan RT, kumpulan RW, posyandu, karang taruna, PKK, tahlil, selapanan dan lain-lain yang ada di desa.

Aspirasi dari beberapa kelembagaan kemasyarakatan tersebut kemudian dikumpulkan dan dimusyawarahkan dengan tokoh-tokoh masyarakat dalam musyawarah desa (Musdes). Dari Musyawarah Dusun dibahas tentang prioritas pembangunan desa yang akan dilaksanakan yang kemudian dituangkan dalam RPJM Des. RPJM Des tersebut hanya membahas tentang prioritas pembangunan yang akan dilaksanakan. Sedangkan untuk detail biaya yang diperlukan dituangkan dalam RKP Des. RKP Des tersebut digunakan sebagai dasar untuk penetapan APBDes.

\section{DAFTAR PUSTAKA}

PP 43 tahun 2014

Undang -undang No 6 Tahun 2014 Tentang Desa

Peraturan Pemerintah No 12 Tahun 2011 Tentang Peraturan Pelaksanaan Undang-undang No 6 Tahun 2014 tentang Desa. 